\title{
Clinical and epidemiological impact of varicella infection in children prior to the introduction of the varicella vaccine in the national immunization schedule of Argentina
}

\author{
Silvina E. Neyro, M.D. ${ }^{a}$, Fausto M. Ferolla, M.D. ${ }^{a, b}$, Claudia Molise, M.D. ${ }^{b}$, \\ Patricia Stach, M.D. ${ }^{b}$, Pablo Romano, M.D. ${ }^{c}$, Silvia Marone, M.D. ${ }^{d}$, \\ Arturo de Mena, M.D. ${ }^{a}$, Fabiola Plat, M.D. ${ }^{a}$, Carla Voto, M.D. ${ }^{a}$, \\ Pedro Soto, M.D. ${ }^{a}$, Laura Bustos, M.D. ${ }^{c}$, Cecilia Clavijo, M.D. ${ }^{c}$, Daniel Murgo, M.D. ${ }^{d}$, \\ Daniel Dozoretz, M.D. ${ }^{d}$, Jorge Fiorentino, M.D. ${ }^{b}$ and Eduardo L. López, M.D. ${ }^{a}$
}

\section{ABSTRACT}

Introduction. In Argentina, an estimated 400000 varicella cases occur annually. Given the under-recording of existing cases, the actual burden of disease is unknown.

Objective. To assess the burden of varicella before the introduction of the varicella vaccine in the national immunization schedule.

Materials and methods. Retrospective, analytical, observational study carried out in three hospitals of Argentina. Review of medical records from outpatient visits to the Emergency Department and from patients younger than 18 years hospitalized for varicella. Period: 1/2011-12/2013. Results. A total of 382782 outpatients were seen; $3367(0.88 \%)$ corresponded tovisitsduetovaricella; $57.6 \%$ were $\leq 4$ years old. A total of $164(4.9 \%)$ patients required hospitalization, with an overall hospitalization rate of 65.3/10 000 hospitalized patients/year (95\% confidence interval [CI]: 55.4-76.5); hospitalization rate in healthy children: 57.2/10 000 (95 \% CI: 67.7-48.0); median age: 31.5 months. The most common causes of hospitalization were skin and/or soft tissue infections $(61.1 \%)$ and respiratory infections $(10.1 \%)$. Also, $54.3 \%$ were treated with acyclovir and $73.1 \%$, with antibiotics. Bacteremia developed in 5/67 patients $(7.5 \%)$, all cases were caused by Gram-positive cocci and occurred in immunocompetent patients. Out of 19 immunocompromised patients, $36.8 \%$ had complications (5 skin and/or soft tissue infection and 2 pneumonia cases). The median length of stay was 4 days, which is significantly more prolonged in immunocompromised patients. One patient required intensive care. No patient died.

Conclusion. The burden of disease was significant, with a considerable impact in patients without an underlying disease.

Key words: varicella, pediatrics, burden of disease, outpatient care, hospitalization.

Silvina E. Neyro, M.D.: silvinaneyro@gmail.com

Funding:

None.

Conflict of interest:

None.

Received: 1-25-2018 Accepted: 7-19-2018
To cite: Neyro SE, Ferolla FM, Molise C, Stach P, et al. Clinical and epidemiological impact of varicella infection in children prior to the introduction of the varicella vaccine in the national immunization schedule of Argentina. Arch Argent Pediatr 2019;117(1):12-18.

\section{INTRODUCTION}

Varicella is an acute infectious disease that results in the primary infection with the varicella-zoster virus. It is one of the most common exanthematous diseases of childhood. Most cases occur during the first decade of life, and only $10 \%$ of young adults remain susceptible. ${ }^{1}$ It is considered a benign disease of childhood but it may cause complications, mostly among adults ${ }^{2-5}$ and immunocompromised patients. . $^{2,4,6}$ Healthy children are also exposed to developing complications (from skin and soft tissue infections [SSTIs] to systemic infections associated with high morbidity and mortality). 2,4,6-8

In Argentina, the National Health Surveillance System has recorded 150 000-200 000 cases of varicella annually, with a rate of approximately 250-450 cases / 100000 inhabitants. However, it has been estimated that more than 400000 new cases occur each year. ${ }^{9}$ Such under-recording generates ignorance on the actual impact of the burden of varicella in Argentina in relation to outpatient visits, hospitalization rates (HRs), and complications. This situation has also been evidenced in other countries of this region. ${ }^{2}$ Given the scarce data available, it is relevant to collect evidence to determine the size of the problem in the period before the introduction of the varicella vaccine in the national immunization schedule and to establish the baseline and subsequently assess the impact of the national immunization strategy. In Argentina, the varicella vaccine was 
introduced in the national immunization schedule in July 2015 as a single dose (at 15 months old). ${ }^{9}$

The objective of this study was to assess the burden of varicella in three hospitals of Argentina before the introduction of the vaccine.

\section{MATERIALS AND METHODS}

Retrospective, analytical, and observational study carried out in three hospitals of Argentina: Hospital de Niños "Dr. Ricardo Gutiérrez" (a tertiary care, public pediatric hospital of the Autonomous City of Buenos Aires), Hospital Interzonal General de Agudos "Evita" (a public hospital in Lanús, province of Buenos Aires), and Hospital "Marcial V. Quiroga" (a public general hospital in the province of San Juan).

Data were collected by reviewing the record books of outpatient visits at the Emergency Department and the medical records of patients younger than 18 years seen or hospitalized for varicella or related complications during the period between January 2011 and December 2013.

Varicella was diagnosed by the pediatricians of the Emergency Department or the pediatric hospitalization units based on clinical and evolutionary characteristics of disease. The following information was collected: demographic characteristics, presence/type of comorbidities, history of immunization, presence/type of complications, length of hospital stay in days, results of laboratory tests and imaging studies (if any is requested as part of the routine practice), need for surgical procedures, and antibiotic and antiviral use.

This study was approved by the ethics committees of participating hospitals.

\section{Statistical analysis}

The Stata software, version 11.2, was used for statistical analysis. Results were expressed as arithmetic mean or median and standard deviation for quantitative outcome measures and as percentage for qualitative outcome measures. Rates were estimated together with the corresponding $95 \%$ confidence intervals (CIs). Different statistical association tests were used depending on the type of outcome measure: to compare proportions, the $\chi^{2}$ test or Fisher's test and to compare mean values, Student's t test or Mann-Whitney $U$ test, as applicable. A value of $p<0.05$ was considered statistically significant.

\section{RESULTS \\ Outpatient visits for varicella}

During the study period, 382782 outpatients were seen at the Emergency Department; $3367(0.88 \%)$ were diagnosed with varicella, which accounted for an incidence of 88 cases / 10000 outpatient visits / year (95\% CI: 85-91) (Table 1). Among them, $57.6 \%$ were children younger than 4 years, with a median age of 48 months (interquartile range [IQR]: 24-72); $50.1 \%$, were girls. The analysis of age subgroups showed that 333 cases were diagnosed among infants younger than 1 year (28 were hospitalized); 1607 cases, among children aged 1-4 years (79 were hospitalized); 1401 cases, among children aged 5-14 years (43 were hospitalized), and 26 cases, among children aged 15-18 years ( 3 were hospitalized).

A marked seasonality was observed in the number of visits for varicella, which predominated between June and November, consistent with the winter and early spring months (Figure 1).

The development of exanthema was the most common reason for consultation ( $\mathrm{n}=3178$, $94.4 \%$ ). Other reasons included fever, respiratory distress, injury bacterial superinfection, and follow-up.

A total of 3339 children (99.2\%) were previously healthy. Only 28 patients $(0.8 \%)$ had a comorbidity; the most frequent comorbidities were cancer $(\mathrm{n}=6,21.4 \%)$ and rheumatic conditions $(n=6,21.4 \%)$, followed by other immunodeficiencies $(\mathrm{n}=5,17.8 \%)$ and hematological disorders $(n=4,14.2 \%)$; the rest were 2 cases of epilepsy, 1 of asthma, 1 of atopic dermatitis, 1 of heart disease, 1 of chronic nephropathy and 1 of chronic hepatopathy.

At the time of the outpatient visit, 401 patients $(11.9 \%)$ had a varicella-associated complication and 33 , more than one. The most common complication was SSTI $(n=321,80 \%)$, followed by respiratory conditions $(\mathrm{n}=30,7.5 \%)$ and neurological disorders $(n=13,3.2 \%)$.

\section{Hospitalizations for varicella}

Out of 3367 patients with varicella who attended the Emergency Department, 164 were hospitalized (4.9\%, $95 \%$ CI: 4.2-5.6): $8.4 \%$ of infants younger than 1 year (95\% CI: 5.7-11.9), $4.9 \%$ of children aged $1-4$ years (95\% CI: 3.9-6.1), $3.1 \%$ of children aged 5-14 years (95\% CI: 2.2-4.1), and $11.5 \%$ of children older than 14 years $(95 \%$ CI: 2.4-30.2). The analysis included 153 patients 
(93.3\% of all patients) because 11 were referred to a different facility. The overall HR for varicella was 65.3 cases / 10000 hospitalizations / year (95\% CI: 55.4-76.5) (Table 1). Among hospitalized patients, $80(52.6 \%)$ were boys and their median age was 31 months (IQR: 15$64)$; the median age was significantly older among immunocompromised patients (median: 67 months old, IQR: 33-120, $p<0.001$ ). Only 3/ 102 previously healthy children $(2.9 \%)$ had a history of immunization with a single dose.

The source of transmission was known in 50 patients (32.9\%): $38(76 \%)$ had a primary case within the family; only $3(6 \%)$ had received some sort of prophylaxis after exposure.

The median time of exanthema progression at the time of hospital admission was 4 days (IQR: 2-5 days) and the mean duration of fever was 2 days (IQR: $1-3$ days).

Out of all hospitalized patients, $134(87.6 \%)$ were immunocompetent and were admitted due to varicella-associated complications (Table 2). Considering only healthy children, the HR was 57.2/10 000 hospitalizations/year (95\% CI: 67.7-48.0). There were 19 (12.4\%) immunocompromised patients (10 were receiving prolonged corticosteroid therapy; 5 had blood diseases and cancer; 1 had received a liver

FIGURE 1. Seasonality of outpatient visits for varicella, per year

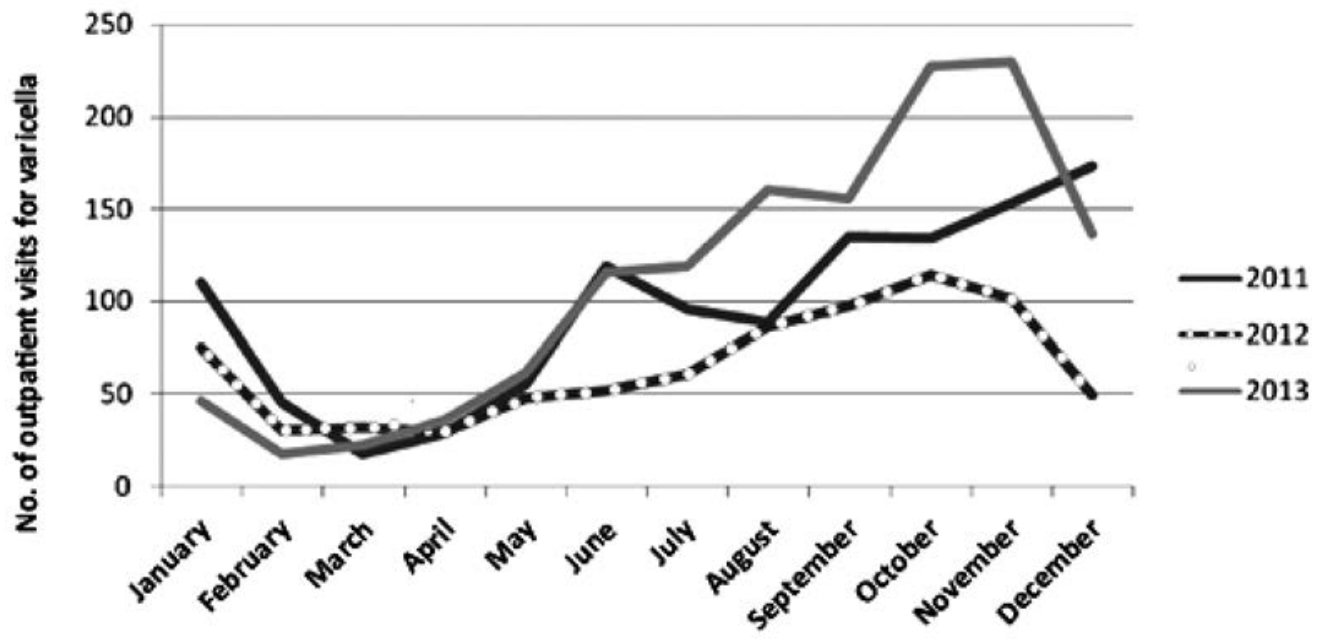

TABLE 1. Outpatient visits and hospitalizations for varicella and in total

\begin{tabular}{|c|c|c|c|c|c|c|c|c|c|c|c|c|c|}
\hline & \multicolumn{4}{|c|}{$\begin{array}{l}\text { Hospital de Niños } \\
\text { “Dr. Ricardo Gutiérrez" }\end{array}$} & \multicolumn{4}{|c|}{$\begin{array}{l}\text { Hospital General } \\
\text { de Agudos "Evita" }\end{array}$} & \multicolumn{4}{|c|}{$\begin{array}{c}\text { Hospital } \\
\text { “Dr. Marcial V. Quiroga" }\end{array}$} & \multirow{2}{*}{$\begin{array}{c}\text { Total } \\
2011-2013 \\
\end{array}$} \\
\hline & 2011 & 2012 & 2013 & Total & 2011 & 2012 & 2013 & Total & 2011 & 2012 & 2013 & Total 2 & \\
\hline $\begin{array}{l}\text { Outpatient } \\
\text { visits for } \\
\text { varicella }\end{array}$ & 602 & 422 & 811 & 1835 & 179 & 171 & 243 & 593 & 480 & 184 & 275 & 939 & 3367 \\
\hline $\begin{array}{l}\text { Total outpatient } \\
\text { visits }\end{array}$ & 58643 & 65972 & 60646 & 185261 & 25716 & 26126 & 27512 & 79354 & 41589 & 39747 & 36831 & 118167 & 382782 \\
\hline $\begin{array}{l}\text { Outpatient } \\
\text { visits for } \\
\text { varicella / } 10000 \\
\text { visits in total }\end{array}$ & 103 & 64 & 134 & 99 & 70 & 65 & 88 & 75 & 115 & 46 & 75 & 79 & 88 \\
\hline $\begin{array}{l}\text { Hospitalizations } \\
\text { for varicella }\end{array}$ & 32 & 27 & 38 & 97 & 5 & 6 & 12 & 23 & 19 & 9 & 16 & 44 & 164 \\
\hline $\begin{array}{l}\text { Hospitalizations } \\
\text { in total }\end{array}$ & 5310 & 5778 & 5603 & 16691 & 1492 & 1389 & 1423 & 4304 & 1265 & 1450 & 1390 & 4105 & 25100 \\
\hline $\begin{array}{l}\text { Hospitalizations } \\
\text { for varicella / } 10000 \\
\text { hospitalizations } \\
\text { in total }\end{array}$ & 60 & 47 & 68 & 58 & 34 & 43 & 84 & 53 & 150 & 62 & 115 & 107 & 65.3 \\
\hline
\end{tabular}


transplant; and 3 were receiving other type of immunosuppressive therapy).

Unlike what was observed in healthy children, out of all hospitalized immunocompromised patients, only $7(36.8 \%)$ had infectious complications: 5, an SSTI and 2, pneumonia. No significant differences were observed in the studied population in terms of age and time of disease progression in relation to the type of complication.

A blood count was done at the time of admission in 138 children (90.2\%); the leukocyte count was $10567 \pm 5750 / \mathrm{mm}^{3}$. A liver function

TABLE 2. Complications of varicella that led to the hospitalization of immunocompetent patients

\begin{tabular}{lc}
\hline Complication & $\mathbf{n}=\mathbf{1 3 4}(\mathbf{\%})$ \\
\hline Skin and soft tissue infections & $93(60.8)$ \\
Impetigo & $66(43.1)$ \\
Cellulitis & $15(9.8)$ \\
Erythroderma & $8(5.2)$ \\
Orbital/preseptal cellulitis & $4(2.6)$ \\
Respiratory involvement & $18(11.8)$ \\
Pneumonitis & $10(6.5)$ \\
Pneumonia & $8(5.2)$ \\
Neurological involvement & $13(8.5)$ \\
Ataxia & $5(3.3)$ \\
Febrile seizure & $4(2.6)$ \\
Encephalitis & $4(2.6)$ \\
Hemorrhagic varicella/purpura & $5(3.3)$ \\
Sepsis & $3(2.0)$ \\
Vomiting/diarrhea & $2(1.3)$ \\
\hline
\end{tabular}

test was also done in 60 patients. A transient increase in liver enzymes over $80 \mathrm{U} / \mathrm{L}$ was observed in 9 patients (15\%). A chest X-ray was requested in 60 patients $(39.2 \%) ; 18$ (30\%) showed pathological findings: 10 had pneumonitis and 8, pneumonia. Five soft tissue ultrasounds were done; the diagnosis of cellulitis was confirmed in 4 of them. Two patients with encephalitis had a computed tomography done; no pathological findings were observed. Nine patients with neurological symptoms had a lumbar tap: 1 showed increased cerebrospinal fluid cellularity (52 leukocytes $/ \mathrm{mm}^{3}$ ) and 1 had hyperproteinorrhachia $(94 \mathrm{mg} / \mathrm{dL})$. No microbiological diagnosis was confirmed in any cerebrospinal fluid sample.

Acyclovir treatment was indicated in 18 immunocompromised patients $(94.7 \%)$ and in 51 immunocompetent patients $(38.1 \%)$ for a median of 7 days (IQR: 6-10 and 5-7, respectively). Antipyretics were indicated to 93 patients $(60.8 \%)$ for a median of 2 days (IQR: 1-3); 21 of these $(22.6 \%)$ received ibuprofen and no associated adverse events were observed.

Bacterial cultures were done in 70 patients: 67 sets of blood count tests were done and 5 $(7.5 \%)$ were positive (2 cases of Streptococcus pyogens, 2 of methicillin-resistant Staphylococcus aureus [MRSA], and 1 of methicillin-susceptible Staphylococcus aureus [MSSA]); 2 cultures of purulent material obtained from healthy skin puncture were done and resulted positive

TABLE 3. Clinical, laboratory, and evolutionary characteristics of hospitalized patients $(n=163)$

\begin{tabular}{|c|c|c|c|}
\hline $\begin{array}{l}\text { Outcome } \\
\text { measure }\end{array}$ & $\begin{array}{c}\text { Immunocompetent } \\
\text { patients }(n=134)\end{array}$ & $\begin{array}{c}\text { Immunocompromised } \\
\text { patients }(n=19)\end{array}$ & $p$ \\
\hline Age in months, $\mathrm{m} \pm \mathrm{SD}$ & $40 \pm 38$ & $78 \pm 54$ & $<0.001$ \\
\hline Male sex, n $(\%)$ & $69(51.4)$ & $11(57.9)$ & ns \\
\hline Known contact, n $(\%)$ & $42(31.3)$ & $8(42.1)$ & ns \\
\hline 2nd intrafamilial contact, $\mathrm{n}(\%)$ & $31(23.1)$ & $7(36.8)$ & ns \\
\hline \multicolumn{4}{|l|}{ Laboratory parameters } \\
\hline Leukocyte count $\left(/ \mathrm{mm}^{3}\right), \mathrm{m} \pm \mathrm{SD}$ & $11059 \pm 5831(\mathrm{n}=121)$ & $7066 \pm 3637(\mathrm{n}=17)$ & 0.007 \\
\hline $\mathrm{AST}>80 \mathrm{U} / \mathrm{L}, \mathrm{n}(\%)$ & $5 / 45(11.1)$ & $4 / 14(28.6)$ & ns \\
\hline $\mathrm{ALT}>80 \mathrm{U} / \mathrm{L}, \mathrm{n}(\%)$ & $6 / 46(13)$ & $3 / 14(21.4)$ & ns \\
\hline \multicolumn{4}{|l|}{ Course } \\
\hline Days of progression until consultation, $\mathrm{m} \pm \mathrm{SD}$ & $4.3 \pm 2.5$ & $2.1 \pm 1.3$ & $<0.001$ \\
\hline With complications, n (\%) & $134(100)$ & $7(36.8)$ & - \\
\hline Total number of days with fever, $\mathrm{m} \pm \mathrm{SD}$ & $2.4 \pm 1.9(\mathrm{n}=107)$ & $2.2 \pm 2.0(\mathrm{n}=13)$ & ns \\
\hline Total length of stay (days), $\mathrm{m} \pm \mathrm{SD}$ & $4.3 \pm 3.3$ & $6.2 \pm 2.5$ & 0.017 \\
\hline Total number of days with antibiotics, $\mathrm{m} \pm \mathrm{SD}$ & $9.7 \pm 2.8(\mathrm{n}=94)$ & $10.4 \pm 3.9(\mathrm{n}=9)$ & ns \\
\hline Total number of days with acyclovir, $\mathrm{m} \pm \mathrm{SD}$ & $6.9 \pm 3.6(n=51)$ & $7.3 \pm 1.9(\mathrm{n}=18)$ & ns \\
\hline
\end{tabular}

m: mean; SD: standard deviation; ns: not significant; AST: aspartate aminotransferase,

ALT: alanine aminotransferase. 
(1 case of Streptococcus pyogenes and 1 of MSSA); and Streptococcus pyogenes was isolated in 1 throat swab. All patients with bacteremia were immunocompetent, had an SSTI and a significantly higher leukocyte count than the rest: $19200 \pm 4487 / \mathrm{mm}^{3}$ versus $10679 \pm 747 / \mathrm{mm}^{3}$ $(p=0.004)$. White blood cell counts $\geq 11900 / \mathrm{mm}^{3}$ were associated with bacteremia and showed a $100 \%$ sensitivity and a $69 \%$ specificity; white blood cell counts $\geq 12900 / \mathrm{mm}^{3}$ showed an $80 \%$ sensitivity and a $72.1 \%$ specificity (area under the curve: 0.84, $95 \%$ CI: 0.71-0.97).

The median length of hospital stay was 4 days (IQR: 2-6), which was significantly longer in children with immunodeficiency (median of 3 [IQR: $2-6]$ versus 6 [IQR: 5-8]; $p=0.017$ ). Only 1 patient, who was previously healthy, had encephalitis and required intensive care. No patient died.

Table 3 is a summary of the clinical, laboratory, and evolutionary characteristics of hospitalized patients.

\section{DISCUSSION}

According to the World Health Organization, the information on the burden of disease, the incidence of varicella, and the consequences of secondary infections in developing countries is limited. ${ }^{10}$

Although varicella is a notifiable disease in Argentina, ${ }^{11}$ it is significantly under-recorded; an important number of cases are not reported because patients do not attend or have not access to the health care system or because they are seen at a public or private facility that fails to systematically report cases to the surveillance system, especially when managing outpatients. ${ }^{12}$

This study provides information on the impact of varicella infections in our setting. Data on the overall HR (including immunocompromised patients) and the HR of immunocompetent patients were collected from 3 hospitals with different health care modalities and located in different areas of the country; the fact that the study period covered 3 consecutive years helped to reduce the bias of potential inter-annual variations.

Our findings show that varicella generates a considerable hospital demand, especially in previously healthy children: an average of 22 outpatients were seen for varicella per week per hospital. Most of these outpatient visits $(99.2 \%)$ and hospitalizations $(87.6 \%)$ were in previously healthy patients.
The proportion of varicella patients who were hospitalized out of all recorded cases was $4.9 \%$ (95\% CI: 4.2-5.6), similar to what has been published in a recent meta-analysis that assessed the incidence of varicella in Latin America and the Caribbean, which observed a $5.8 \%(2.6-10.1 \%)$ incidence. ${ }^{12}$ That study also reported a HR of 43 cases (95\% CI: $24-$ 66)/ 10000 hospitalizations/year among children younger than 16 years, which was one third lower than the HR estimated in our study. In the Netherlands, where the vaccine has not been introduced, Van Lier et al. ${ }^{13}$ reported an incidence of 68 cases / 10000 hospitalizations / year in children younger than 16 years, similar to that observed in our setting. In Chile, HRs were reported to range from 14.8 to $16.3 / 1000$ reported cases; whereas in Panama, reports were 5 times higher than those observed in developed countries. ${ }^{2,8}$ Most likely, case under-reporting and the barriers for an active surveillance account for such partial variability. $2,8,12,14$

Before the availability of the varicella vaccine in the United States, approximately 4 million cases occurred each year. ${ }^{2,3}$ Of these, about 10000 required hospitalization (25 every 10000 ) and 100 died. Several articles published in the United States estimated that the universal immunization with the varicella vaccine during childhood was beneficial, with a benefit-cost ratio of 2.1:6.9. . $^{8,15}$

Few investigations have been made available that assessed the differential impact of the infection between children with and without comorbidities. A study conducted in Turkey in the pre-vaccine era reported an overall HR of $107 / 10000$ children younger than 17 years, whereas 87/10 000 children were previously healthy, i.e., $81.6 \%{ }^{4}$ In our population, the HR in previously healthy children was somewhat lower $(12.4 \%)$ than the overall rate.

In countries where the vaccine has been introduced, both the incidence and the morbidity and mortality of varicella reduced to a large extent. ${ }^{16-18}$ In Spain, the communities that decided to administer the vaccine to infants and adolescents showed that the mean HR went from 39 to 21 hospitalizations / 100000 inhabitants, with a $43 \%$ reduction in the post-vaccine period. ${ }^{19}$

In our region, the first Latin American country that introduced the varicella vaccine in its official immunization schedule was Uruguay, where outpatient visits and hospitalizations reduced by $87 \%$ and $81 \%$, respectively. ${ }^{18,20}$ 
In our study, more than half of outpatient visits $(57.6 \%)$ and hospitalizations $(65 \%)$ occurred in children younger than 5 years, which is similar to what was observed in the United States before the introduction of the vaccine. ${ }^{21,22}$ In our population, infants younger than 1 year and adolescents older than 14 years were 1.7 and 3.7 times at a higher risk for hospitalization than the rest of the cases.

Although varicella is not considered a priority public health problem, ${ }^{10}$ the socioeconomic impact of a disease that affects practically all children, forcing them to miss school and their caregivers to miss work should not be underestimated. The length of hospital stay in our patients was shorter than that reported in Panama, ${ }^{9}$ although similar to what has been described in other countries. ${ }^{4,12,21}$ The median length of stay in our setting was 4 days (IQR: 2 to 9 days). Valentim et al. estimated, in Brazil, that the parents of hospitalized children missed between 5 and 15 work days. ${ }^{23}$

A striking finding was that the source of transmission was known in approximately one third of patients and that only $6 \%$ received some sort of secondary prophylaxis, in spite of the national and international recommendations in this regard. ${ }^{1,9,24,25}$ SSTIs, respiratory conditions, and neurological disorders were the main complications in our patients. It is worth noting that SSTIs predominated $(80 \%$ among outpatients and $61 \%$ among inpatients). In the bibliography, the frequency of this complication ranges from $3 \%$ to $61 \%$, which is lower than that observed in our study. ${ }^{2-4,7,8,12,15}$

The prevalence of bacteremia was $7.5 \%$; all children who developed this complication were immunocompetent and had an SSTI. A leukocyte count above $11900 / \mathrm{mm}^{3}$ at the time of admission would allow to predict it, with a high sensitivity $(100 \%)$ and an acceptable specificity $(69 \%)$. The main isolated microorganisms were MRSA and Streptococcus pyogenes. Bacterial superinfection with Streptococcus pyogenes in children with varicella has been reported in different parts of the world..$^{2,6}$ The emergence of MRSA and its eventual association with a greater severity should be considered when defining the initial empiric antibiotic therapy. ${ }^{26}$

Immunocompromised children with varicella were hospitalized; less than half had complications; $94.7 \%$ received intravenous acyclovir for a median of 7 days. Some authors have proposed oral outpatient treatment for patients with risk factors, no complications and an adequate possibility of follow-up. ${ }^{27-29}$
This study defines an important baseline for the subsequent assessment of the impact of the national immunization strategy, especially in relation to the health system demand and varicella-associated morbidity and mortality in our setting.

\section{CONCLUSIONS}

In our study, a significant burden of varicella was recorded in the 3 assessed hospitals, which results in a relevant hospital demand and a considerable HR.

The greatest impact was observed among patients without comorbidities. Most cases occurred in patients younger than 5 years. Varicella-associated complications were observed most of all in infants younger than 1 year and previously healthy adolescents.

\section{REFERENCES}

1. American Academy of Pediatrics. Varicella-Zoster Infections. In: Pickering LK, Baker CJ, Kimberlin DW, Long SS, eds. Red Book. 2012. Report of the Committee on Infectious Diseases. 29th ed. Elk Grove Village, IL: American Academy of Pediatrics; 2012.Pages.774-89.

2. Abarca K, Hirsch T, Potin M, et al. Complicaciones en niños con varicela en cuatro hospitales de Santiago - Chile: espectro clínico y estimación de costos. Rev Med Chile. 2001; 129(4):397-404.

3. Choo PW, Donahue JG, Manson JA, Platt R. The epidemiology of varicella and its complications. J Infect Dis. 1995; 172(3):706-12.

4. Özdemir H, Çandır MO, Karbuz A, et al. Chickenpox complications, incidence and financial burden in previously healthy children and those with an underlying disease in Ankara in the pre-vaccination period. Turk J Pediatr. 2011; 53(6):614-25.

5. Pierik JG, Gumbs PD, Fortanier SA, et al. Epidemiological characteristics and societal burden of varicella zoster virus in the Netherlands. BMC Infect Dis. 2012; 12:110.

6. Aebi C, Ahmed A, Ramilo O. Bacterial complications of primary varicella in children. Clin Infect Dis. 1996; 23(4):698-705.

7. Jackson MA, Burry VF, Olson LLC. Complications of varicella requiring hospitalization in previously healthy children. Pediatr Infect Dis J. 1992; 11(6):441-5.

8. Sáez-Llorens X, de Suman O, de Morós D, Rubio MP. Complicaciones y costos asociados a varicela en niños inmunocompetentes. Rev Panam Salud Pública. 2002; 12(2):111-6.

9. Dirección de Control de Enfermedades Inmunoprevenibles, Ministerio de Salud de la Nación, Argentina. Lineamientos técnicos: Fundamentos de la Introducción de la Vacuna contra Varicela al Calendario Nacional de Inmunizaciones 2015. [Accessed on: January 15 ${ }^{\text {th }}$ 2018]. Available at: http: / / www.msal.gob.ar/images / stories / bes / graficos / 0000000774cnt-2015-04_lineamientos-varicela. pdf.

10. Organización Mundial dela Salud. Vacunas contra varicela. [Accessed on: December 15 $\left.5^{\text {th }}, 2017\right]$. Available at: http: / / www.who.int/immunization/Varicella_spanish.pdf.

11. Ministerio de Justicia y Derechos Humanos. Ley 15.465. Notificación Obligatoria de los casos de enfermedades 
infecciosas. Buenos Aires, Argentina: 24 de octubre de 1960. [Accessed on: January $15^{\text {th }}, 2018$ ]. Available at: http: / / servicios.infoleg.gob.ar/infolegInternet / anexos / 195000-199999/195093/norma.htm.

12. Bardach A, Cafferata ML, Klein K, et al. Incidence and Use of Resources for Chickenpox and Herpes Zoster in Latin America and the Caribbean - A Systematic Review and Meta-analysis. Pediatr Infect Dis J. 2012; 31(12):1263-8.

13. Van Lier A, van der Maas NA, Rodenburg GD, et al. Hospitalization due to varicella in the Netherlands. BMC Infect Dis. 2011; 11:85.

14. Ministerio de Salud de Chile, Departamento de Epidemiología. Varicela. Situación epidemiológica, Chile 2007-2013. [Accessed on: December 20 ${ }^{\text {th }}, 2017$ ]. Available at: http: / / www.minsal.cl/epidemiologia.

15. Lieu TA, Cochi SL, Black SB, et al. Cost effectiveness of a routine varicella vaccination program for US children. JAMA. 1994; 271(15):375-81.

16. Heininger U, Seward JF. Varicella. Lancet. 2006; 368(9544):1365-76.

17. Chaves SS, López AS, Watson TL, et al. Varicella in infants after implementation of the US varicella vaccination program. Pediatrics. 2011; 128(6):1071-7.

18. Quian J, Rüttimann R, Romero C, et al. Impact of universal varicella vaccination on 1-year-olds in Uruguay: 1997-2005. Arch Dis Child. 2008; 93(10):845-50.

19. Ciaravino G, Sagrado MJ, Martínez de Aragón M, et al. Informe sobre la situación de la varicela y del herpes zóster en España, 1999-2012. Madrid: Centro Nacional de Epidemiología, 2014. [Accessed on: December 15 ${ }^{\text {th }}$, 2017]. Available at: http://www.isciii.es/ISCIII/es/ contenidos/fd-servicios-cientifico-tecnicos/fd-vigilanciasalertas / fd-enfermedades / fd-enfermedades-preveniblesvacunacion/InformeVaricela_HZ_1998-2012.pdf.
20. Ulloa-Gutiérrez R, Miño G, Odio C, et al. Vaccinepreventable diseases and their impact on Latin American children. Expert Rev Vaccines. 2011; 10(12):1671-3.

21. Galil K, Brown C, Lin F, Seward J. Hospitalizations for varicella in the United States, 1988 to 1999. Pediatr Infect Dis J. 2002; 21(10):931-5.

22. Davis MM, Patel MS, Gebremariam A. Decline in varicellarelated hospitalizations and expenditures for children and adults after introduction of varicella vaccine in the United States. Pediatrics. 2004; 114(3):786-92.

23. Valentim J, Sartori AM, de Soárez PC, et al. Costeffectiveness analysis of universal childhood vaccination against varicella in Brazil. Vaccine. 2008; 26(49):6281-91.

24. Paganini H. Varicela. In:Paganini H. Infectología Pediátrica. Buenos Aires: Interamericana; 2007.Pages.1098-105.

25. Marin M, Güris D, Chaves SS, et al. Prevention of Varicella: Recomendations of the Advisory Committee on Immunization Practices (ACIP). MMWR Recomm Rep. 2007; 56(RR-4):1-40.

26. Raulin O, Durand G, Gillet Y, et al. Toxin profiling of Staphylococcus aureus strains involved in varicella superinfection. J Clin Microbiol. 2010; 48(5):1696-700.

27. Rodríguez BrieschkeM, Sarkis C, Rodríguez T, et al. Varicela en el niño inmunocomprometido en la era del aciclovir. Arch Argent Pediatr. 2004; 102(1):8-12.

28. Marcó del Pont J. Varicela: nuevas conductas frente a una enfermedad común en pediatría. Arch Argent Pediatr. 2004;102(1):5-7.

29. Luedicke N, Pueyo S, Rezzonico G, Lancieri I. Evolución dela infección por virus varicela-zóster en niños infectados perinatalmente con el virus de la inmunodeficiencia humana. Arch Argent Pediatr. 2004; 102(1):18-21. 